\title{
Chronic imipramine treatment-induced changes in acetylcholinesterase (EC 3.1.1.7) activity in discrete rat brain regions
}

R. Camarini and M.A.C. Benedito

\author{
Departamento de Psicobiologia, Escola Paulista de Medicina, \\ Universidade Federal de São Paulo, 04023-062 São Paulo, SP, Brasil
}

Correspondence

M.A.C. Benedito

Departamento de Psicobiologia EPM, UNIFESP

Rua Botucatu, 862

04023-062 São Paulo, SP

Brasil

Fax: 55 (011) 539-0155

Research supported by FAPESP and Associação Fundo de Incentivo à Psicofarmacologia (AFIP).

R. Camarini was the recipient of

a FAPESP fellowship.

Received November 28, 1996 Accepted June 3, 1997

\begin{abstract}
Cholinergic as well as monoaminergic neurotransmission seems to be involved in the etiology of affective disorders. Chronic treatment with imipramine, a classical antidepressant drug, induces adaptive changes in monoaminergic neurotransmission. In order to identify possible changes in cholinergic neurotransmission we measured total, membrane-bound and soluble acetylcholinesterase (Achase) activity in several rat brain regions after chronic imipramine treatment. Changes in Achase activity would indicate alterations in acetylcholine (Ach) availability to bind to its receptors in the synaptic cleft. Male rats were treated with imipramine $(20 \mathrm{mg} / \mathrm{kg}$, ip) for 21 days, once a day. Twenty-four hours after the last dose the rats were sacrificed and homogenates from several brain regions were prepared. Membranebound Achase activity (nmol thiocholine formed $\mathrm{min}^{-1} \mathrm{mg}$ protein ${ }^{-1}$ ) after chronic imipramine treatment was significantly decreased in the hippocampus $($ control $=188.8 \pm 19.4$, imipramine $=154.4 \pm 7.5$, $\mathrm{P}<0.005)$ and striatum (control $=850.9 \pm 59.6$, imipramine $=742.5 \pm$ $34.7, \mathrm{P}<0.005)$. A small increase in total Achase activity was observed in the medulla oblongata and pons. No changes in enzyme activity were detected in the thalamus or total cerebral cortex. Since the levels of Achase seem to be enhanced through the interaction between Ach and its receptors, a decrease in Achase activity may indicate decreased Ach release by the nerve endings. Therefore, our data indicate that cholinergic neurotransmission is decreased after chronic imipramine treatment which is consistent with the idea of an interaction between monoaminergic and cholinergic neurotransmission in the antidepressant effect of imipramine.
\end{abstract}

\section{Introduction}

Cholinergic neurotransmission is involved in many aspects of central nervous system function, such as learning and memory $(1,2)$ and rapid eye movement sleep generation $(3,4)$. It also seems to be involved in patho-
Key words

- Acetylcholinesterase

- Imipramine

- Brain

- Antidepressants logical conditions such as Alzheimer's disease (2) and depression $(5,6)$.

Imipramine, one of the most extensively studied tricyclic antidepressants, inhibits 5hydroxytryptamine (5-HT) uptake both in vitro and in vivo and chronic treatment induces adaptive changes in brain monoamin- 
ergic neurotransmission (7-12). Janowsky et al. (6) proposed that depression in humans may be associated with overactive cholinergic and decreased monoaminergic neurotransmission. Data in the literature have shown that imipramine, besides having a serotonergic action, may also have a cholinergic effect since it binds to the muscarinic receptor $(13,14)$. Therefore, it seems worthwhile to study the effect of imipramine on neurotransmitters other than monoamines.

Acetylcholinesterase (Achase, EC 3.1.1.7) is an important constituent of cholinergic neurotransmission (15) and hydrolyzes acetylcholine (Ach) in the synaptic cleft, thus terminating its action. The number of Achase molecules can be up-regulated (16) or down-regulated (17). Inhibition of Achase leads to a down-regulation of cholinergic receptors $(18,19)$. The levels of Achase appear to be controlled by the interaction of Ach with its receptor, with an enhanced interaction increasing the levels of Achase (20). Therefore, Achase can be used as an index of cholinergic function, and changes in enzyme activity may indicate alterations in the availability of Ach at the level of its receptors.

A few investigators have studied the effect of antidepressants on Achase activity. To our knowledge, only Geoffroy et al. (21) have reported the effect of chronic imipramine treatment on Achase activity in brain regions. However, these authors assayed the enzyme activity in whole homogenates and in their experimental design added behavioral manipulations to drug treatment, making it difficult to interpret their results in terms of the effect of the drug alone on Achase activity.

In the present study we report a decrease in the activity of membrane-bound Achase in the striatum and hippocampus after chronic imipramine treatment. Our data suggest an interaction between monoaminergic-cholinergic neurotransmission in the brain which may be involved in the antidepressant effect of the drug.

\section{Material and Methods}

\section{Subjects}

Male Wistar rats, 3 months old, weighing 250-300 g, from our own breeding facilities were used in the experiment. After weaning, the rats were kept 3 to a wire cage under controlled temperature $\left(22^{\circ} \mathrm{C}\right)$ and on a 12 -h light-dark cycle (lights on from 7:00 to 19:00 h). The animals had free access to food and water until sacrifice.

Imipramine hydrochloride (Ciba-Geigy Co., São Paulo) diluted in distilled water was administered intraperitoneally, once a day for 21 days (around 9:00 a.m.), at a dose of $20 \mathrm{mg} / \mathrm{kg}$ ( $0.1 \mathrm{ml} / 100 \mathrm{~g}$ body weight). Control rats received vehicle. Control and treated rats were sacrificed $24 \mathrm{~h}$ after the last dose. The dose of imipramine and the time-course of treatment were chosen on the basis of available data showing significant changes in brain neurotransmission.

\section{Tissue preparation}

After decapitation, the brains were excised and kept on a cooled Petri dish on crushed ice. Brains were washed superficially with isotonic saline to clear the tissue of blood. Different brain regions (total cerebral cortex, hippocampus, thalamus, striatum, pons and medulla oblongata) were dissected immediately. Tissue was weighed and kept in cold $0.32 \mathrm{M}$ sucrose buffered with Tris to $\mathrm{pH}$ 7.4.

\section{Homogenate preparation}

Homogenates $(5 \% \mathrm{w} / \mathrm{v})$ were prepared in ice-cold $0.32 \mathrm{M}$ sucrose using glass homogenizer tubes and a motor-driven Teflon ${ }^{\mathrm{TM}}$ pestle and tissue fractions were prepared according to Chubb and Smith (22). Homogenates were centrifuged at $900 \mathrm{~g}$ for $10 \mathrm{~min}$ at $0^{\circ} \mathrm{C}$. The supernatant was collected and centrifuged at $100,000 \mathrm{~g}$ for $60 \mathrm{~min}$ at $4^{\circ} \mathrm{C}$. 
The resulting supernatant was the source of soluble Achase and the resulting pellet was resuspended in the original volume. This latter preparation was the source for membrane-bound Achase. Enzyme activity was also measured in the $900 \mathrm{~g}$ supernatant. Homogenates were kept at $-20^{\circ} \mathrm{C}$ until assayed.

\section{Determination of Achase activity}

Achase activity was determined using the method of Ellman et al. (23) modified for microassays. Acetylthiocholine was used as substrate at a final assay concentration of 1 $\mathrm{mM}$. All materials, including reagents and homogenates, were kept on crushed ice before incubation. Enzyme activity was determined in duplicate for both samples and blanks. One hundred $\mu \mathrm{l}$ of buffer-substrate ( $0.1 \mathrm{M}$ sodium phosphate buffer, $\mathrm{pH} 8$, plus acetylthiocholine iodide) was pipetted into a microtube and $5 \mu$ of the homogenate was added. Blanks were obtained by adding 15 $\mu \mathrm{l}$ of $2.4 \mathrm{~N}$ perchloric acid to the tubes before incubation. The tubes were incubated for $30 \mathrm{~min}$ in a shaking water bath at $37^{\circ} \mathrm{C}$. After the addition of perchloric acid the enzyme activity tubes were centrifuged at $2,250 \mathrm{~g}$ for $15 \mathrm{~min}$ at $0^{\circ} \mathrm{C}$. An aliquot of $50 \mu \mathrm{l}$ was pipetted into another tube and $500 \mu$ of Ellman's reagent was added. After standing for $15 \mathrm{~min}$ at room temperature, samples were read in a Beckman DU-2 spectrophotometer using microcuvettes at $412 \mathrm{~nm}$. Proteins were assayed by the method of Lowry et al. (24) using bovine serum albumin as standard.

The activity of Achase is reported as nmol thiocholine formed $\mathrm{min}^{-1} \mathrm{mg}$ protein ${ }^{-1}$. The assay was set up to allow the reaction to be linear for both tissue concentration and incubation time. To test for the contribution of butyrylcholinesterase to the hydrolysis of Ach, the enzyme activity was measured using butyrylthiocholine as the substrate at 1 $\mathrm{mM}$ final concentration. Since the activity was very low $(<5 \%)$, as also shown by others
(25), no inhibitor of butyrylcholinesterase was used.

\section{Reagents}

All reagents used were from Sigma Chemical Co. (St. Louis, MO) and were analytical grade. Twice-distilled water prepared with an all-glass apparatus was used throughout the assays.

\section{Statistical analysis}

The Student $t$-test was used to test for statistical differences ( $\mathrm{P} \leq 0.05$, two-tailed).

\section{Results}

The data in Table 1 show that chronic imipramine treatment induced a highly significant decrease in Achase activity in the hippocampus in the $900 \mathrm{~g}$ supernatant fraction $(\mathrm{t}=3.04$, df $=10, \mathrm{P}<0.02)$ and in the $100,000 \mathrm{~g}$ pellet $(\mathrm{t}=4.04, \mathrm{df}=10, \mathrm{P}<0.005)$ but no change was observed in the $100,000 \mathrm{~g}$ supernatant. A highly significant decrease in Achase activity (Table 1) was also observed in the striatum after chronic imipramine in both the $900 \mathrm{~g}$ supernatant $(\mathrm{t}=4.63, \mathrm{df}=10$, $\mathrm{P}<0.001)$ and $100,000 \mathrm{~g}$ pellet $(\mathrm{t}=3.87, \mathrm{df}=$ $10, \mathrm{P}<0.005)$. No difference was observed in

Table 1 - Achase activity in the hippocampus and striatum of rats chronically treated with imipramine.

Achase activity is reported as nmol thiocholine formed $\mathrm{min}^{-1} \mathrm{mg}$ protein ${ }^{-1}$. Results are reported as mean $\pm \mathrm{SD}$ for 6 animals in each group. Final acetylthiocholine concentration in the assay was $1 \mathrm{mM}$. ${ }^{*} \mathrm{P}<0.02,{ }^{*} \mathrm{P}<0.005,{ }^{*} * \mathrm{P}<0.001$ compared to control (Student $t$-test).

\begin{tabular}{lccr}
\hline Brain region & $\begin{array}{c}\text { Supernatant } \\
900 \mathrm{~g}\end{array}$ & $\begin{array}{c}\text { Pellet } \\
100,000 \mathrm{~g}\end{array}$ & $\begin{array}{c}\text { Supernatant } \\
100,000 \mathrm{~g}\end{array}$ \\
\hline $\begin{array}{l}\text { Hippocampus } \\
\text { Control } \\
\text { Imipramine }\end{array}$ & $141.2 \pm 18.3$ & $188.8 \pm 19.4$ & $101.6 \pm 15.0$ \\
Striatum & $112.0 \pm 14.6^{*}$ & $154.4 \pm 7.5^{* *}$ & $92.0 \pm 12.5$ \\
$\quad$ & & & \\
Control & & & \\
Imipramine & $659.9 \pm 28.9$ & $850.9 \pm 59.6$ & $305.6 \pm 23.1$ \\
& $581.5 \pm 29.8^{* * *}$ & $742.5 \pm 34.7^{* *}$ & $274.8 \pm 46.0$
\end{tabular}


the $100,000 \mathrm{~g}$ supernatant.

Chronic imipramine treatment induced a small but significant increase in Achase activity in the medulla oblongata only in the $900 \mathrm{~g}$ supernatant fraction ( control $=143.3 \pm$ 8.2 , imipramine $=157.6 \pm 8.0 ; \mathrm{t}=3.04, \mathrm{df}=$ $10, \mathrm{P}<0.02)$. There was no statistically significant difference between the $100,000 \mathrm{~g}$ pellet and the supernatant. In the pons, a small but statistically significant increase was also observed only in the $900 \mathrm{~g}$ supernatant $($ control $=200.6 \pm 7.9$, imipramine $=$ $213.3 \pm 6.9 ; \mathrm{t}=2.90, \mathrm{df}=10, \mathrm{P}<0.02)($ data not shown). No statistically significant differences in Achase activity after chronic imipramine were observed for the thalamus or total cerebral cortex in any of the fractions assayed (data not shown).

\section{Discussion}

The main finding of the present study was a significant decrease in membranebound Achase activity in the hippocampus and striatum after chronic imipramine treatment. Although we also observed statistically significant differences in other brain regions (medulla oblongata and pons), they were obtained only in the total fraction (900 $g$ ) and were small in amplitude. Therefore, from a biological point of view, they may have no great significance for the effect of the drug.

The decrease in Achase activity may lead to changes in cholinergic receptors after chronic imipramine treatment. Data in the literature have shown that chronic imipramine treatment did not change the number of muscarinic receptors in the striatum $(8,26)$ or hippocampus (26). However, there is a report showing an increased number of receptors in the striatum (27). Due to the known diversity of both muscarinic and nicotinic brain cholinergic receptors $(28,29)$ the possibility of a change in these receptors cannot be ruled out.

The decrease in Achase activity in the striatum and hippocampus after chronic imipramine treatment may indicate a secondary change induced by the drug acting primarily on serotonergic synapses through serotonergic afferents to these regions. Cholinergic neurons in the striatum are mostly intrinsic to this brain region and afferent connections from serotonergic raphe nuclei to the striatum have been described (30). Cholinergic projections to the hippocampus through the fornix arise in basal forebrain neurons and the hippocampus also receives projections from serotonergic raphe nuclei (30). These anatomical data seem to favor an indirect action of imipramine on cholinergic neurotransmission.

The striatum is one of the richest cholinergic areas in the brain and all cholinergic markers are highly concentrated in this brain region $(31,32)$. The striatum is involved in the control of motor behaviors but its involvement with affective behavior has not yet been described, although Graybiel (33) has raised this possibility. Therefore, the effect of imipramine on this brain region may be involved in its antidepressant effect. Cholinergic neurons in the striatum are under dopaminergic afferent control and chronic imipramine treatment has been shown to induce a decrease in $D_{1}$ dopaminergic receptors $(8,11)$ and in $\mathrm{B}_{\max }$ of $\left[{ }^{3} \mathrm{H}\right] \mathrm{DTG}$ binding to the haloperidol-sensitive sigma sites (34). On the other hand, imipramine binds with high affinity to striatum membranes and this site seems to be located on the 5-HT transporter (35). Moreover, imipramine decreases $\left[{ }^{3} \mathrm{H}\right] 5-\mathrm{HT}$ binding to striatal membranes (9). These data support the view that the effect of imipramine on Achase activity is not a direct one.

Chronic imipramine has been shown to induce several effects in the hippocampus, including sensitization of hippocampal CA1 neurons to the inhibitory effect of 5-HT (36), potentiation of the increase in the neuronal firing rate induced by a $D_{2}$ dopaminergic agonist (37), an increase of the suppressant 
effect of the electrical stimulation of the afferent 5-HT pathway on the firing activity of CA3 pyramidal neurons (38), a decrease in 5-HT2 receptor sites (7), a decrease in 5HT and beta-adrenergic receptor sites (9), a decrease in 5-HT transporter sites (12), and a reduction of inhibition of forskolin-stimulated adenylate cyclase by 5-HT (10). These data indicate that, as observed in the striatum, the changes in Achase activity observed after chronic imipramine may also reflect alterations induced by the drug primarily on serotonergic neurotransmission. The hippocampus is a brain structure involved in emotions, being part of the limbic system (39), and changes in hippocampal cholinergic neurotransmission induced by chronic imipramine may be involved in the antidepressant effect of the drug.

Recent data in the literature using microdialysis techniques have shown an interaction between brain serotonergic and cholinergic neurotransmission. Drugs enhancing serotonergic neurotransmission when admin- istered acutely increase the release of Ach in vivo in the hippocampus (40). We did not find data in the literature on the release of Ach after chronic imipramine treatment which could help establish a relationship between the decrease in Achase activity and Ach levels in the hippocampus.

The indirect effect of imipramine on cholinergic neurons suggested by our results may also involve its metabolite desipramine which is an antidepressant drug that inhibits the uptake of noradrenaline. Therefore, the changes in Achase activity may also involve noradrenergic neurotransmission.

In conclusion, our results show that chronic imipramine treatment changes membrane-bound Achase activity only in some brain regions, probably leading to a change in cholinergic neurotransmission. Our data obtained in rats seem to support Janowsky's proposal (6) of an involvement of cholinergic neurotransmission in human depression.

\section{References}

1. Dekker JAM, Connor DJ \& Thal LJ (1991). The role of cholinergic projections from the nucleus basalis in memory. Neuroscience and Biobehavioral Reviews, 15: 299317.

2. Haroutunian V, Kanof PD, Tsuboyama GK, Campbell GA \& Davis KL (1986). Animal models of Alzheimer's disease: behavior, pharmacology, transplants. Canadian Journal of Neurological Sciences, 13: 385-393.

3. Velazquez-Moctezuma J, Gillin JC \& Shiromani PJ (1989). Effect of specific $M_{1}, M_{2}$ muscarinic receptor agonists on REM sleep generation. Brain Research, 503: 128-131.

4. Velazquez-Moctezuma J, Shalanta M, Gillin JC \& Shiromani PJ (1991). Cholinergic antagonists and REM sleep generation. Brain Research, 543: 175-179.

5. Dilsaver SC (1986). Cholinergic mechanisms in depression. Brain Research Reviews, 11: 285-316.
6. Janowsky DS, El-Yousef MK, Davis JM \& Sekerke HJ (1972). A cholinergic-adrenergic hypothesis of mania and depression. Lancet, 2: 632-635.

7. Burnet PW, Michelson D, Smith MA, Gold PW \& Sternberg EM (1994). The effect of chronic imipramine administration on the densities of 5-HT1A and 5-HT2 receptors and the abundances of 5-HT receptor and transporter mRNA in the cortex, hippocampus and dorsal raphe of three strains of rat. Brain Research, 638: 311-324.

8. Klimek V \& Nielsen M (1987). Chronic treatment with antidepressants decreases the number of $\left[{ }^{3} \mathrm{H}\right]-\mathrm{SCH} 23390$ binding sites in the rat striatum and limbic system. European Journal of Pharmacology, 139: 163-169.

9. Maggi A, U'Prichard DC \& Enna SJ (1980). Differential effects of antidepressant treatment on brain monoaminergic receptors. European Journal of Pharmacology, 61: 91-98.
10. Newman $M E$, Ben-Zeev $A$ \& Lerer $B$ (1991). Chloroamphetamine did not prevent the effects of chronic antidepressants on 5-hydroxytryptamine inhibition of forskolin-stimulated adenylate cyclase in rat hippocampus. European Journal of Pharmacology, 207: 209-213.

11. Papp M, Klimek V \& Willner $P$ (1994). Parallel changes in dopamine $D_{2}$ receptor binding in limbic forebrain associated with chronic mild stress-induced anhedonia and its reversal by imipramine. Psychopharmacology, 115: 441-446.

12. Watanabe $Y$, Sakai RR, McEwen BS \& Mendelson S (1993). Stress and antidepressant effects on hippocampal and cortical 5-HT1A and 5-HT2 receptors and transport sites for serotonin. Brain Research, 615: 87-94

13. Rehavi M, Maayani S \& Sokolovsky M (1977). Tricyclic antidepressants as antimuscarinic drugs: in vivo and in vitro studies. Biochemical Pharmacology, 26: 15591567. 
14. Snyder SH \& Yamamura HI (1977). Antidepressants and the muscarinic cholinergic receptor. Archives of General Psychiatry, 34: 236-239.

15. Brimijoin S (1983). Molecular forms of acetylcholinesterase in brain, nerve and muscle: nature, localization and dynamics. Progress in Neurobiology, 21: 291322.

16. Moudgil VK \& Kanungo MS (1973). Effect of age of the rat on induction of acetylcholinesterase of the brain by 17 beta-estradiol. Biochimica et Biophysica Acta, 329: 211-220.

17. Battie CN \& Moran N (1990). Sympathectomy alters acetylcholinesterase expression in adult rat heart. Cardiovascular Research, 24: 335-339.

18. Costa LG \& Murphy SD (1983). [3H]-Nicotine binding in rat brain: alteration after chronic acetylcholinesterase inhibition. Journal of Pharmacology and Experimental Therapeutics, 226: 392-397.

19. Ehlert FJ, Kokka N \& Fairhurst AS (1980). Altered $\left[{ }^{3} \mathrm{H}\right]$-quinuclidinyl benzylate binding in the striatum of rats following chronic cholinesterase inhibition with diisopropylfluorophosphate. Molecular Pharmacology, 17: 24-30.

20. Fernandez HL \& Hodges-Savola CA (1992). Trophic regulation of acetylcholinesterase isoenzymes in adult mammalian skeletal muscles. Neurochemical Research, 17: 115-124.

21. Geoffroy M, Tvede K, Christensen AV \& Schou JS (1991). The effect of imipramine and lithium on "learned helplessness" and acetylcholinesterase in rat brain. Pharmacology, Biochemistry and Behavior, 38: 93-97.

22. Chubb IW \& Smith AD (1975). Isoenzymes of soluble and membrane-bound acetylcholinesterase in bovine splanchnic nerve and adrenal medulla. Proceedings of the Royal Society of London. Series B, 191: 245-261.
23. Ellman GL, Courtney KD, Andres Jr V \& Featherstone RM (1961). A new and rapid colorimetric determination of acetylcholinesterase activity. Biochemical Pharmacology, 7: 88-95.

24. Lowry OH, Rosebrough NJ, Farr AL \& Randall RJ (1951). Protein measurement with the Folin phenol reagent. Journal of Biological Chemistry, 193: 265-275.

25. Hobbiger F \& Lancaster R (1971). The determination of acetylcholinesterase activity of brain slices and its significance in studies of extracellular acetylcholinesterase. Journal of Neurochemistry, 18: 17411749.

26. Goldman ME \& Erickson CK (1983). Effects of acute and chronic administration of antidepressant drugs on the central cholinergic nervous system. Neuropharmacology, 22: 1215-1222.

27. Koide $T$ \& Matsushita $H$ (1981). An enhanced sensitivity of muscarinic cholinergic receptor associated with dopaminergic receptor subsensitivity after chronic antidepressant treatment. Life Sciences, 28: 1139-1145.

28. Arneric SP, Sullivan JP \& Williams M (1995). Neuronal nicotinic acetylcholine receptors. In: Bloom FE \& Kupfer DJ (Editors), Psychopharmacology: The Fourth Generation of Progress. Raven Press, New York, 95-110.

29. Ehlert FJ, Roeske WR \& Yamamura HI (1995). Molecular biology, pharmacology and brain distribution of subtypes of the muscarinic receptor. In: Bloom FE \& Kupfer DJ (Editors), Psychopharmacology: The Fourth Generation of Progress. Raven Press, New York, 111-124.

30. Woolf NJ (1991). Cholinergic systems in mammalian brain and spinal cord. Progress in Neurobiology, 37: 475-524.

31. Hoover DB, Muth EA \& Jacobowitz DM (1978). A mapping of the distribution of acetylcholine, choline acetyltransferase and acetylcholinesterase in discrete areas of rat brain. Brain Research, 153: 295306.
32. Stavinoha WB, Weintraub ST \& Modak AT (1974). Regional concentration of choline and acetylcholine in the rat brain. Journal of Neurochemistry, 23: 885-886.

33. Graybiel AM (1995). The basal ganglia. Trends in Neurosciences, 18: 60-62.

34. Shirayama $Y$, Nishikawa $T$, Umino A \& Takahashi K (1993). p-Chlorophenylalanine-reversible reduction of sigma binding sites by chronic imipramine treatment in rat brain. European Journal of Pharmacology, 237: 117-126.

35. Rotondo A, Giannaccini G, Quattrone C Marazziti D, Martini C, Cassano GB \& Lucacchini A (1994). Solubilization and characterization of $\left[{ }^{3} \mathrm{H}\right]$-imipramine and $[3 \mathrm{H}]$-paroxetine binding sites from calf striatum. Neurochemical Research, 19: 1295-1300.

36. Bijak M \& Tokarski K (1994). Prolonged administration of imipramine and (+)oxaprotiline, but not citalopram, results in sensitization of the rat hippocampal CA1 neurons to serotonin ex vivo. Polish Journal of Pharmacology, 46: 163-167.

37. Bijak M (1993). Prolonged treatment with antidepressant drugs on the excitatory effect of quinpirole in hippocampal slices. Polish Journal of Pharmacology, 45: 381390.

38. Chaput Y, de Montigny C \& Blier P (1991) Presynaptic and postsynaptic modifications of the serotonin system by longterm administration of antidepressant treatments. An in vivo electrophysiologic study in the rat. Neuropsychopharmacology, 5: 219-229.

39. Isaacson RL (1982). The Limbic System. 2nd edn. Plenum Press, New York.

40. Saito $H$, Matsumoto $M$, Togashi $H$ \& Yoshioka M (1996). Functional interaction between serotonin and other neuronal systems: Focus on in vivo microdialysis studies. Japanese Journal of Pharmacology, 70: 203-225. 